\title{
Analisis Usability Testing pada User Interface dalam Game Idle Breeder
}

\author{
Agung Riyadi $^{1}$, James ${ }^{2}$ \\ Program Studi Teknik Multimedia dan Jaringan, Jurusan Teknik Informatika \\ Politeknik Negeri Batam \\ agung@polibatam.ac.id ${ }^{1}$,jamesoung123@yahoo.com ${ }^{2}$
}

\begin{tabular}{|c|c|}
\hline Arti & ABSTRACT \\
\hline Article history: & \multirow{9}{*}{$\begin{array}{l}\text { In today's development, children are used to using smart phones or } \\
\text { smartphones. Most of these smartphones run on the Android or IOS } \\
\text { operating system. In smartphones there are applications that can be } \\
\text { used for various purposes. One type of these applications is games. In } \\
\text { this case, there are still many users who play the game having difficulty } \\
\text { understanding the layout and menus that have been presented in a } \\
\text { game, making it difficult for users to play it. In this study the author } \\
\text { will discuss the user experience in the game "idle breeder" Idle Breeder } \\
\text { is a top-down game with an idle genre with a relaxing feel. The } \\
\text { formulation of this research is how to design a user interface in the idle } \\
\text { breeder game and also how to do analysis in terms of user experience } \\
\text { from users. User experience focuses on the comfort and convenience } \\
\text { of users in using idle breeder games (usability) }\end{array}$} \\
\hline Received Des $12^{\text {th }}, 2021$ & \\
\hline Revised Des $20^{\text {th }}, 2021$ & \\
\hline Accepted Des $29^{\text {th }}, 2021$ & \\
\hline Keyword: & \\
\hline User Centered Design & \\
\hline Game & \\
\hline Usability & \\
\hline User Interface & \\
\hline
\end{tabular}

\section{LATAR BELAKANG}

Industri game di Indonesia memiliki potensi besar untuk berkembang dan bersaing di pasar internasional melalui industri kreatif. Untuk mempercepat pengembangan industri kreatif, pemerintah Indonesia melalui Kementerian Perindustrian dan Badan Ekonomi Kreatif (BEKRAF) pada tahun 2015 memasukkan pengembangan game dan aplikasi menjadi sektor pertama dari 16 sektor industri kreatif lainnya [1].

Terlepas dari game yang dinikmati terdapat design yang digunakan untuk mempermudah User Experience. User Experience adalah nilai yang diperoleh pengguna ketika berinteraksi dengan produk atau layanan dalam situasi penggunaan tertentu [2]. Dalam mendesain User Experience, tidak hanya mengutamakan penggunaan dan kegunaan UI, tetapi juga meningkatkan kepuasan pengguna dengan meningkatkan nilai kegunaan aplikasi, kemudahan penggunaan, dan kesenangan pengguna. [3].

Dalam hal ini masih banyak user yang memainkan game kesulitan untuk memahami layout dan menu yang telah disajikan pada sebuah game sehingga mempersulit pengguna dalam memainkan nya, Dalam penelitian ini penulis akan membahas mengenai user experience yang ada pada game "idle breeder" Idle Breeder adalah sebuah game top-down bergenre idle dengan nuansa relaxing. Pemain akan memerankan seorang anak bernama Arma untuk membangun ulang peternakan peninggalan kakeknya. Pemainan ini bisa dimainkan dengan santai oleh kalangan anak-anak hingga remaja.

Maka dari itu rumusan dari penelitian ini adalah bagaimana merancang sebuah user interface pada game idle breeder dan juga bagaimana melakukan analisis dalam segi user experience dari pengguna. User experience berfokus kepada kenyamanan serta kemudahan pengguna dalam menggunakan game idle breeder (usability). Evaluasi user experience dalam penelitian ini menggunakan metode User Centered Design sebagai metode perancangan, diharapkan pengguna dapat menggunakan dan memahami fitur yang ada pada game dengan mudah sehingga experience yang didapatkan sesuai dengan yang diharapkan. 


\section{TINJAUAN PUSTAKA}

Analisis antarmuka pengguna game atau aplikasi sangat sering dilakukan. Hal ini juga dapat dijadikan acuan untuk mengidentifikasi penelitian ini sehingga dapat dibedakan dengan penelitian lainnya. Beberapa penelitian terkait yang menjadi referensi untuk penelitian ini diantaranya, dalam penelitian Miftahul Huda (2020) "Analisis User Experience Pada Game Mobile Legend Versi 1.4.14.4454 Dengan Menggunakan Game-Design Factor Questionnaire" menggunakan metode evaluasi design factor questionnaire, dan metode pengumpulan data kuantitatif deskriptif [4]. Penelitian Putri ayu lestari (2019) membahas tentang "Evaluasi Usability Pada Antarmuka Pengguna Aplikasi PLN Mobile Menggunakan Metode Evaluasi Heuristik" menggunakan metode evaluasi heuristik dengan metode analisis menggunakan serverity rating[5]. Sedangkan pada penelitian Muhammad Jauhari Jawara Perkasa (2019) "Analisis Usability dan Rekomendasi Tampilan pada Game Mobile dengan Kategori Third Person Shooter Menggunakan Metode Heuristic Evaluation (Studi Kasus Game Mobile Rules Of Survival)" dengan menggunakan metode heuristik sebagai metode evaluasi. [6].

\subsection{Game}

Game adalah suatu permainan yang memiliki aturan di mana terdapat pemenang dalam bermain terutama dalam situasi yang tidak serius atau untuk tujuan hiburan. Permainan terdiri dari aturan yang membangun situasi kompetitif dari sekelompok dua atau lebih orang atau pemain dengan memilih strategi yang dirancang untuk mencapai kemenangan. Aturan menentukan tindakan yang dapat dilakukan setiap pemain, jumlah informasi yang diterima setiap pemain selama permainan, dan jumlah menang dan kalah dalam situasi yang berbeda [7].

2.2. User Interface \& User Experience

User interface merupakan interaksi yang terjadi antara program dan pengguna, semua yang terlihat pada layar seperti membaca dalam dokumentasi dan dimanipulasi menggunakan keyboard (atau mouse) juga merupakan bagian dari user interface. User interface memiliki fungsi untuk menghubungkan informasi yang ada pada program kepada pengguna dengan bantuan sistem operasi. dengan demikian dapat juga diartikan sebagai mekanisme inter-relasi atau intergrase total dari perangkat keras dan luna yang membentuk pengalaman berkomputer [8].

UX (user experience) merupakan desain pada program yang digunakan untuk meningkatkan kepuasan dari pengguna nya yang diberikan pada interaksi antara pengguna dengan produk. UX berfungsi untuk membuat sebuah produk aplikasi menjadi lebih mudah untuk digunakan oleh pengguna, dapat dikatakan bahwa ux sebagai elemen keseluruhan pada interaksi pengguna terhadap program mencakup hal seperti susunan, kemudahan dalam mengakses tiap fitur atau halaman yang ada pada program dan sebagainya [9].

2.3. User Centered Design

UCD merupakan paradigma baru dalam pengembangan web dan sistem berbasis aplikasi. Konsep UCD menghadirkan pengguna sebagai pusat dari proses pengembangan sistem. Sasaran/karakteristik, konteks, dan lingkungan sistem semuanya didasarkan pada pengalaman pengguna. [Sepuluh]. Prinsip-prinsip yang termasuk dalam UCD adalah orientasi pengguna, desain terintegrasi, pengujian pengguna, dan desain interaktif.

\subsection{Usability}

Definisi usability adalah pengalaman ketika pengguna berinteraksi dengan aplikasi atau situs web hingga pengguna dapat menggunakan aplikasi atau situs web dengan mudah dan cepat. Sesuatu sangat membantu jika kita dapat menghilangkan atau meminimalkan kesalahan penggunaan dan meningkatkan kegunaan dan kepuasan pengguna [8] Menurut definisi ini, kegunaan yang diusulkan oleh Jacob Nielsen dalam pengujian dalam penelitian Gunakan 5 aspek atau 5 atribut. Diusulkan, yaitu: Kemudahan (learnability) didefinisikan seberapa cepat pengguna mahir dalam menggunakan sistem serta kemudahan dalam penggunaan menjalankan suatu fungsi serta apa yang pengguna inginkan dapat meraka dapatkan.

A. Efisiensi didefinisikan sebagai sumber daya yang dihabiskan untuk mencapai akurasi dan integritas suatu tujuan.Mudah diingat (memorability) didefinisikan sebagai cara untuk mempertahankan kemampuan pengguna untuk mempertahankan pengetahuan setelah jangka waktu tertentu.

B. Errors (kesalahan) didefinisikan sebagai jumlah kesalahan, semua kesalahan oleh pengguna, dan kesalahan oleh pengguna yang membentuk ketidaksesuaian antara pendapat pengguna dan representasi sebenarnya dari sistem.

C. Kepuasan didefinisikan sebagai ukuran subjektif dari ketidaknyamanan dan sikap positif terhadap penggunaan produk, atau bagaimana pengguna memandang sistem. 


\section{METODE PENELITIAN}

Metode Penyelesaian Masalah yang digunakan penulis dalam penelitian ini adalah dengan menggunakan metode User Centered Design. Tahapan metode penerapan ini terbagi menjadi bagian, yaitu:

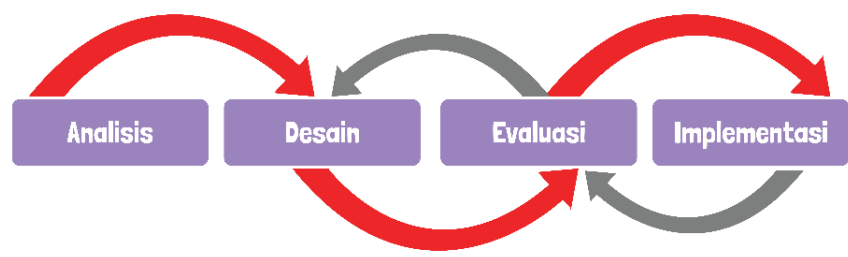

Gambar 1. Metode Perancangan User Centered Design

Selain metode diatas, penulis memakai metode analisis Kuantitatif untuk melakukan analisis pada tahap evaluasi yang dimana penulis menggunakan 30 responden ini berdasarkan pernyataan Roscoe dalam buku terbitan nya yang berjudul Research Methods For Business yang memberikan saran mengenai ukuran sampel yang layak pada sebuah penelitian adalah dari 30 hingga 500 sampel. Dimana sampel yang diambil yaitu dari usia 12 hingga 30 tahun dengan kriteria umum.

\subsection{Analisis}

Pada bagian ini dilakukan analisis terhadap kebutuhan dari aplikasi ini diukur dari lingkup pengguna nya yaitu pada umur 12 hingga 30 tahun dengan kriteria umum. Maka dari itu kebutuhan yang diperlukan pada pembuatan desain user interface kali ini adalah sebagai berikut:

A. Menu lifestock

Menu ini berguna untuk menambahkan jumlah hewan ternak serta kapasitas dari hewan yang bisa ditampung pada suatu pulau.

B. Menu upgrade kandang and research

Menu ini digunakan untuk menambahkan jumlah penghasilan setiap detik nya dimana menu upgrade menggunakan uang untuk menaikkan level nya dan research menggunakan energi untuk menaikkan level nya.

C. Menu quest

Menu ini berisi hal atau misi yang harus dilakukan pemain agar mendapatkan reward atas misi yang telah di selesaikan. Misi tidak akan berganti kecuali misi yang sedang berlangsung telah di selesaikan.

D. Menu option

Menu ini digunakan untuk mengakses pengaturan yang ada pada game, dimana pengaturan nya adalah pengaturan suara dari game dan juga suara dari effect yang ada pada game, terdapat jg menu untuk menampilka fps serta credit yang berguna untuk menampilkan developer dari game.

Berdasarkan uraian menu yang nantinya akan ada pada game ini maka selanjut nya menentukan warna yang digunakan serta tata layout dari desain yang akan dibuat, disini penulis mengambil konsep layout yang simple dan tidak terlalu banyak kata-kata sehingga akan menarik pemain yang berumur muda.

\subsection{Rancangan Game}

Rancangan Game yang penulis gunakan pada game idle breeder ini adalah rancangan core loop dimana rancangan yang mengharuskan pemain melakukan looping pada saat proses dalam bermain game. Rancangan yang digunakan dapat dilihat pada gambar dibawah ini. 


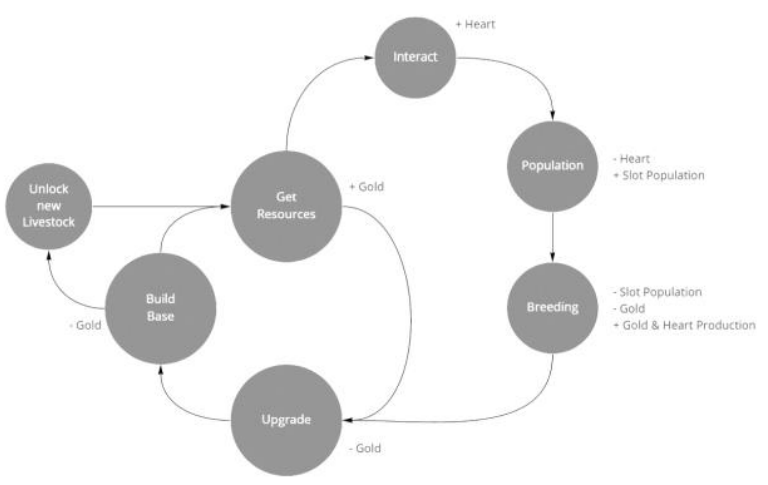

Gambar 7. Rancangan Game Core Loop

3.4. Evaluasi

Langkah selanjutnya ketika sudah melakukan desain terhadap layout menu adalah melakukan evaluasi terhadap hasil sementara yang telah dibuat, dimana tujuan evaluasi ini melihat apakah tujuan pembuatan desain ini sudah tercapai, dimana yang melakukan evaluasi yaitu target pengguna yang nanti nya akan menggunakan game yang telah penulis buat. Pada penelitian ini target pengguna nya yaitu masyarakat umum dengan skala umur 15 hingga 30 tahun dengan tidak ada latar belakang spesifik.

Evaluasi ini dilakukan dengan cara mengumpulkan angket / kuisioner yang nantinya di isi oleh responden, dimana aspek yang di pakai pada kuisioner ini menggunakan aspek usability yang dikembangkan menjadi pertanyaan yang seusai dengan kebutuhan. Berikut merupakan rancangan pertanyaan yang telah disusun.

Tabel 2. Rancangan Pertanyaan Evaluasi

\begin{tabular}{|c|l|}
\hline Kode Pertanyaan & Pertanyaan \\
\hline Kemudahan (learnability) \\
\hline P01 & Menu yang ada pada game ini mudah untuk diakses \\
\hline P02 & Menu yang ada pada game ini mudah untuk dipahami \\
\hline Efisiensi (efficiency) & Dapat memilih menu yang ada pada game dengan cepat \\
\hline P03 & Peletakan posisi menu pada game tidak mengganggu saat sedang bermain \\
\hline P04 & Letak menu yang ada pada game mudah untuk diingat \\
\hline Mudah diingat (memorability) \\
\hline P05 & Semua tombol pada menu dapat dibuka tanpa ada nya kendala \\
\hline Kesalahan dan keamanan (errors) \\
\hline \multicolumn{2}{|c|}{ P06 } \\
\hline Kepuasan (satisfaction) \\
\hline P07 & Saya merasa puas dengan menu yang ditampilkan pada game ini \\
\hline
\end{tabular}

Lalu dari pertanyaan yang telah ada tersebut dilakukan analisis menggunakan rumus likert dan hasil nya dilihat berdasarkan interval skala likert dibawah ini:

1. Angka $80 \%-100 \%=$ Sangat Setuju (SS)

2. Angka $60 \%-79.99 \%=$ Setuju (S)

3. Angka $40 \%-59.99 \%=\operatorname{Netral}(\mathrm{N})$

4. Angka $20 \%-39.99 \%=$ Tidak Setuju (TS)

5. Angka 0\%-19.99\% = Sangat Tidak Setuju (STS)

\section{HASIL DAN ANALISIS}

4.1. Implementasi Desain

Berdasarkan dari hasil rancangan desain dari sebelum nya maka pada tahap ini dilakukan realisasi dari rancangan, berikut hasil dari desain yang telah dibuat:

\section{A. Menu lifestock}

Pada gambar menu dibawah akan tampil setelah pemain memiih menu pada kiri bawah yang akan langsung menuju ke menu lifestock. Dimana pada menu ini tersedia hewan-hewan yang dapat di tambahkan kedalam pertenakan serta kapasitas dari hewan yang dapat ditampung pada satu pulau. 
B. Menu upgrade dan research
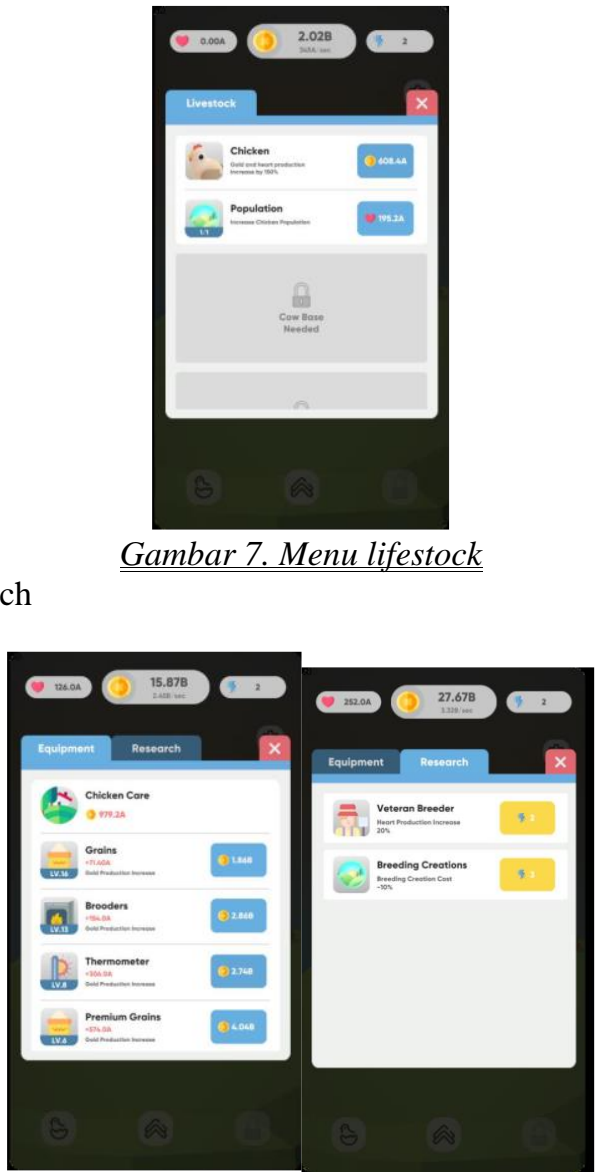

Gambar 8. Menu upgrade dan research

Setelah user memilih menu pada tengah bawah yang akan langsung menuju ke menu upgrade. Dimana pada menu ini tersedia pilihan untuk meningkatkan level dari item-item yang ada pada pertenakan dengan guna untuk menambahkan penghasilan uang yang didapatkan dari pemain.

C. Menu quest

Pada gambar menu dibawah ini akan tampil setelah user memiih menu pada icon bagian kanan yang akan langsung menuju ke menu quest. Dimana pada menu ini tersedia misi yang mengharuskan pemain untuk menjalankan nya dan mendapatkan berbagai macam hadiah ketika berhasil menyelesaikannya.

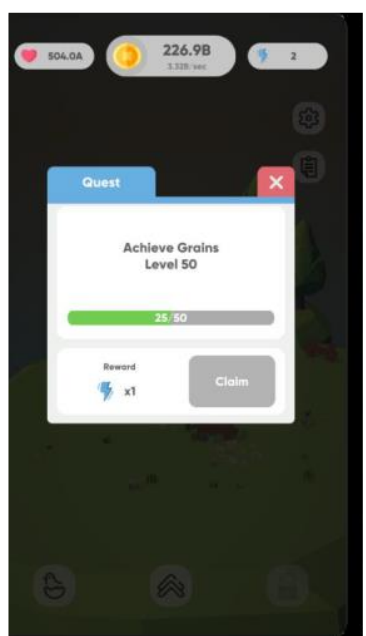

Gambar 9. Menu quest 
D. Menu option

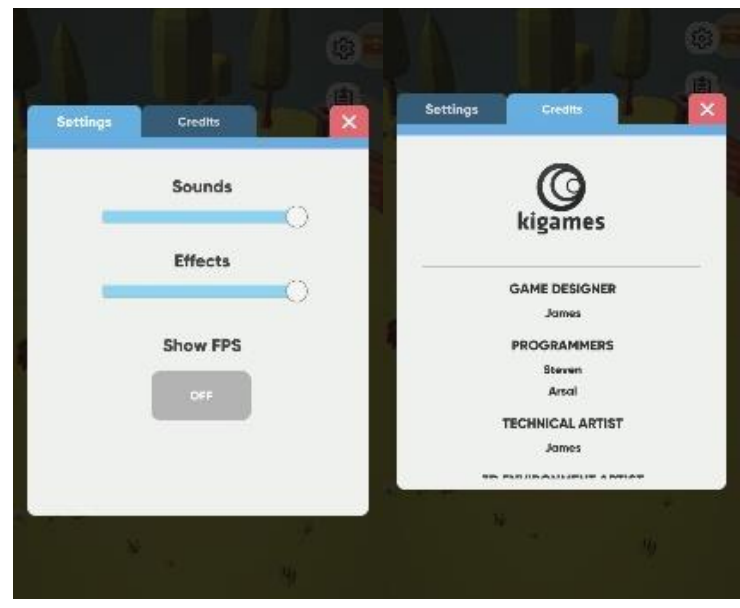

Gambar 10. Menu option

Pada gambar menu diatas akan ditampilkan setelah user memiih menu pada icon bagian kanan yang akan langsung menuju ke menu option. Dimana pada menu ini tersedia pengaturan suara dari game serta terdapat menu untuk menampilkan kredit dari developer pengembang game ini.

\subsection{Evaluasi}

Tahapan ini adalah tahapan melakukan evaluasi terhadap desain yang telah dibuat dan di implementasikan pada game, dimana evaluasi ini memakai bantuan dari pengguna yang sesuai dengan kriteria target penulis. Pengguna diminta untuk memainkan game ini secara menyeluruh dan mencoba seluruh menu yang ada pada game ini, lalu pemain akan diberikan sebuah kuesioner untuk menilai dan mengevaluasi hasil dari implementasi desain yang telah dilakukan pada game ini.

Tabel 3. Hasil Kuesioner

\begin{tabular}{|c|c|c|c|c|c|}
\hline \multirow{2}{*}{ No } & \multicolumn{6}{|c|}{ Pilihan Jawaban } \\
\cline { 2 - 6 } & SS & S & N & TS & STS \\
\hline \multicolumn{7}{|c|}{ Learnability } \\
\hline P1.1 & 7 & 19 & 4 & 0 & 0 \\
\hline P1.2 & 13 & 12 & 5 & 0 & 0 \\
\hline \multicolumn{7}{|c|}{ Efficiency } \\
\hline P2.1 & 17 & 7 & 6 & 0 & 0 \\
\hline P2.2 & 13 & 10 & 7 & 1 & 0 \\
\hline \multicolumn{7}{|c|}{ Memorability } \\
\hline P3.1 & 15 & 8 & 7 & 0 & 0 \\
\hline \multicolumn{7}{|c|}{ Satisfaction } \\
\hline P4.1 & 15 & 8 & 0 & 0 \\
\hline P5.1 & 9 & 14 & 0 & 0 \\
\hline
\end{tabular}

\section{Aspek Learnability}

Pada aspek Learnability terdapat dua pernyataan yaitu P1.1 s/d P1.2. Dan setelah dilakukan perhitungan nilai Index \% didapatkan $82 \%$, dan $85.3 \%$, secara berurut dan didapatkan rata-rata sebesar $83.67 \%$. Jika diinterpretasikan kedalam skala likert, maka menunjukkan bahwa tingkat penilaian termasuk dalam kategori "Sangat Setuju".

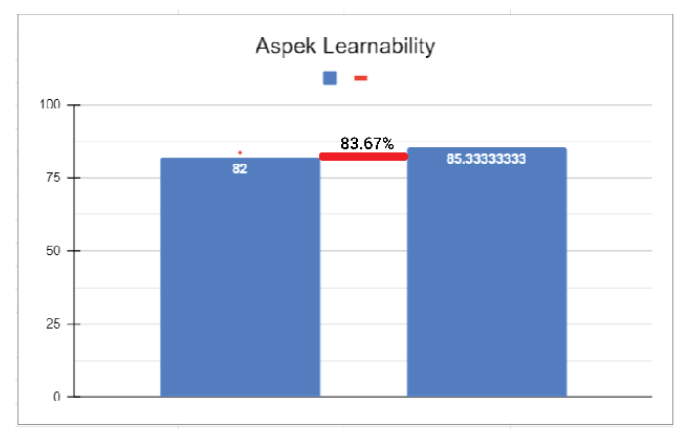


2. Aspek Efficiency

\section{Gambar 12. Aspek Learnability}

Pada aspek Efficiency terdapat dua pernyataan yaitu P2.1 s/d P2.2. Dan setelah dilakukan perhitungan nilai Index \% didapatkan $87.3 \%$, dan $84 \%$, secara berurut dan didapatkan rata-rata sebesar $85.67 \%$. Jika diinterpretasikan kedalam skala likert, maka menunjukkan bahwa tingkat penilaian termasuk dalam kategori "Sangat Setuju".

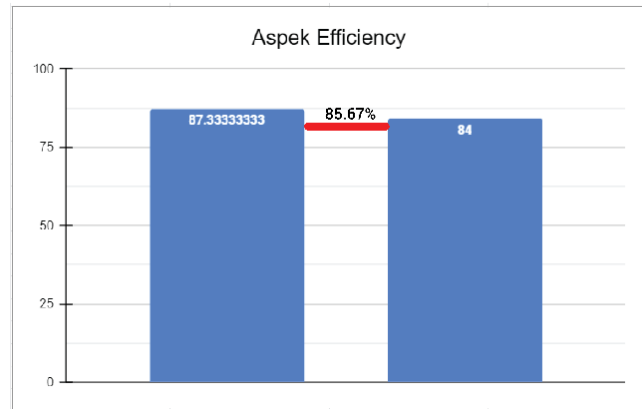

Gambar 13. Aspek Efficiency

3. Aspek Memorability

Pada aspek Memorability terdapat satu pernyataan yaitu P3.1. Dan setelah dilakukan perhitungan nilai Index \% didapatkan 85.3\%. Jika diinterpretasikan kedalam skala likert, maka menunjukkan bahwa tingkat penilaian termasuk dalam kategori "Sangat Setuju".

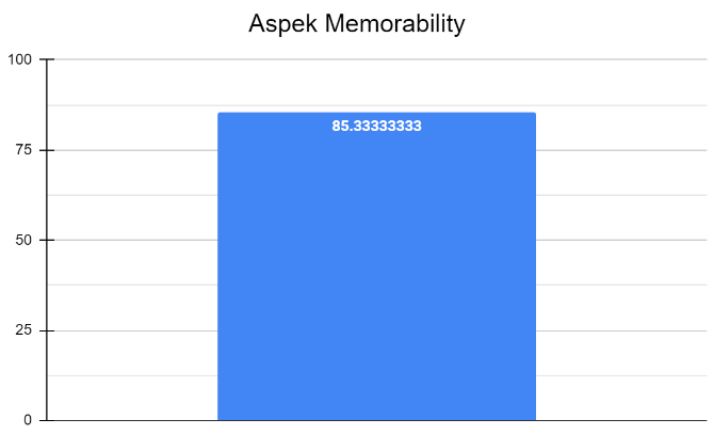

Gambar 14. Aspek Memorability

4. Aspek Errors

Pada aspek Errors terdapat satu pernyataan yaitu P3.1. Dan setelah dilakukan perhitungan nilai Index \% didapatkan $85.3 \%$. Jika diinterpretasikan kedalam skala likert, maka menunjukkan bahwa tingkat penilaian termasuk dalam kategori "Sangat Setuju".

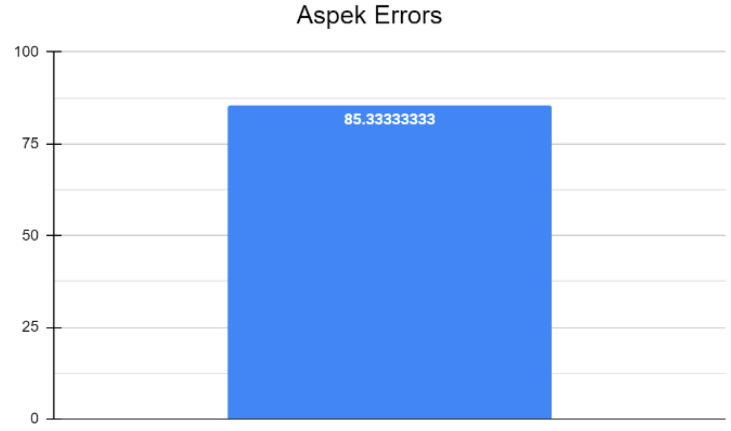

5. Aspek Satisfaction

Gambar 15. Aspek Errors

Pada aspek performance terdapat satu pernyataan yaitu P3.1. Dan setelah dilakukan perhitungan nilai Index \% didapatkan $81.3 \%$. Jika diinterpretasikan kedalam skala likert, maka menunjukkan bahwa tingkat penilaian termasuk dalam kategori "Sangat Setuju". 


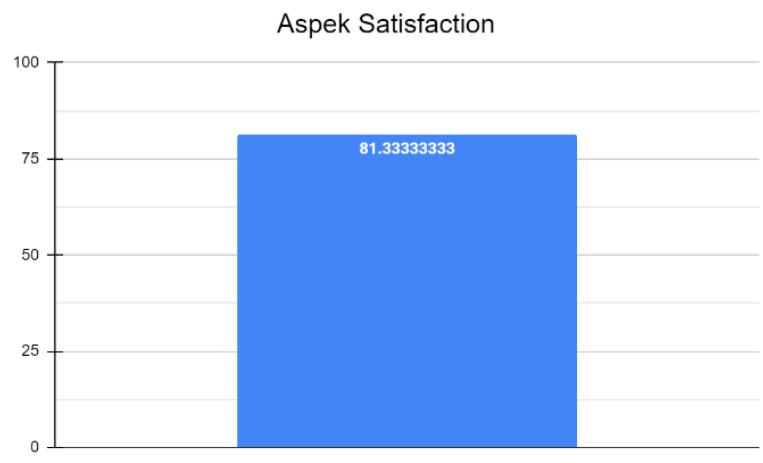

Gambar 16. Aspek Satisfaction

\section{KESIMPULAN}

Beberapa tahapan untuk merancang sebuah user interface pada game ini adalah yang pertama kali dilakukan dengan mendefinisikan menu apa saja yang akan ada pada game ini, setelah itu membuat rancangan sketsa dari layout sesuai jumlah menu yang dibutuhkan serta memilih warna yang sesuai dengan konsep yang dibuat. Setelah itu melakukan implementasi dari rancangan sebelum nya sehingga terbentuk user interface yang telah siap untuk dilakukan evaluasi kepada pengguna.

Hasil dari kuesioner sesuai dengan rancangan yang telah dibuat setelah responden memainkan dengan menggunakan metode likert dan membuat grafik pada tiap aspek pertanyaan sehingga didapatkan rata-rata dari setiap aspek pertanyaan, setelah hasil rata-rata didapatkan selanjutnya membandingkan dengan tabel nilai standar likert sehingga dapat dimasukkan kedalam kategori apa hasil yang didapatkan. Dimana nilai yang didapatkan yaitu pada aspek Learnability pada $83.67 \%$ masuk dalam kategori "sangat setuju", aspek Efficiency pada $85.67 \%$ masuk dalam kategori "sangat setuju", aspek Memorability pada 85.3\% masuk dalam kategori "sangat setuju", aspek Errors pada 85.3\% masuk dalam kategori "sangat setuju", dan aspek Satisfaction pada $81.3 \%$ masuk dalam kategori "sangat setuju". Dengan hasil yang didapatkan dapat di simpulkan bahwa desain user interface yang dibuat dapat memudahkan pengguna dalam menggunakan dan memahaminya.

\section{REFERENSI}

[1] AR.R.T Hidayat and A Y Asmara 2017. Creative industry in supporting economy growth in Indonesia: Perspective of regional innovation System. IOP Conf. Ser: Earth Environ. Sci.70 012031

[2] Gavin M. \& David S., 2007. Making User Experience a Business Strategy. Towards a UX Manifesto 2007, 3-7 September 2007, Landcaster: UK.

[3] Tolle, Herman., Aryo Pinandito., Agi Putra Kharisma dan Ratih Kartika Dewi. , 2017. Pengembangan Aplikasi Perangkat Bergerak. UB Press. Malang

[4] Miftahul Huda. (2020). Analisis User Experience Pada Game Mobile Legend Versi 1.4.14.4454 Dengan Menggunakan Game-Design Factor Questionnaire. Politeknik Kutoarjo

[5] Putri Ayu lestari. (2019). Evaluasi Usability Pada Antarmuka Pengguna Aplikasi PLN Mobile Menggunakan Metode Evaluasi Heuristik. Jurnal Pengembangan Teknologi Informasi dan Ilmu Komputer

[6] Muhammad Jauhari Jawara Perkasa. (2019). Analisis Usability dan Rekomendasi Tampilan pada Game Mobile dengan Kategori Third Person Shooter Menggunakan Metode Heuristic Evaluation (Studi Kasus Game Mobile Rules Of Survival). Jurnal Pengembangan Teknologi Informasi dan Ilmu Komputer

[7] Putra ,Febriyanto Pratama. 2012. “Pembuatan Game Animasi 3D Role Playing Game Untuk Pendidikan Budaya Dengan Unity3D dan Bahasa Pemrograman C\#.”. Skripsi. Surakarta: Fakultas Komunikasi dan Informatika Jurusan Teknik Informatika. Universitas Muhammadiyah Surakarta.

[8] Alfiera Rizki Rachmani, A. B. (2019). Sistem Informasi Akuntansi Sebagai Alat Komunikasi Perusahaan Dengan Para Stakeholder .

[9] Amborowati, Armadyah. (2008). Rancangan Pameran Online Menggunakan Metode UCD (User Centered Design). STMIK AMIKOM. Yogyakarta.

[10] Nielsen, Jakob and L. Mack, Robert. 1994. "Usability Inspection Methods". Sunsoft. 